\title{
THE UNCANNY IMP: AN ANALYSIS OF FREUD'S UNCANNY IN EDGAR ALLAN POE'S THE IMP OF THE PERVERSE AND WILLIAM WILSON
}

Amanda Leonardi de Oliveira (UFRGS) Elaine Indrusiak (UFRGS)

Recebido em 14 abr 2019. Amanda Leonardi de Oliveira é Mestranda do Aprovado em 26 ago 2019. Programa de Pós-Graduação do Instituto de Letras da Universidade Federal do Rio Grande do Sul (Área de Concentração: Estudos de Literatura; Linha de Pesquisa: Sociedade, (Inter)textos e Tradução nas Línguas Estrangeiras Modernas).

Elaine Indrusiak é Graduada em Letras, bacharelado, pela UFRGS, pesquisadora independente e escritora de ficção. Co-autora do artigo Shakesperare through the centuries: the bard and his sources, publicado pela UCS em Anais do 5을 Encontro da Rede Sul Letras no século XXI, Volume I - Trabalhos completos, 2017. Autora de contos publicados pelas editoras Argonautas, Illuminari, Multifoco e Andross. Colaboradora dos sites NotaTerapia, Conexão Literatura e Artrianon.

Abstract: This article discusses Edgar Allan Poe's The Imp of the Perverse and William Wilson in the light of Sigmund Freud's psychoanalytical concepts, particularly that of the uncanny. Both tales explore aspects of the human psyche which would be explained later in Freud's ground-breaking work. The first part of the text explores the dialogue between literature 
and the Freudian concept of the uncanny. Next, the concept is applied to a reading of Poe's The Imp of The Perverse, a short story in which Poe presents his own theory of the segmented nature of the human mind. In the third part the concepts of perverseness and of the uncanny help us shed light on Poe's William Wilson, one of the world's most celebrated Gothic doppelgänger tales. The interpretive readings and the parallels drawn reinforce the dialogue between the fictional work of the American short story writer and Freud's revolutionary ideas that laid the foundations of modern psychology.

Keywords: Edgar Allan Poe, Sigmund Freud, Uncanny, Imp of the Perverse, William Wilson.

Resumo: Este artigo discute os contos $O$ Demônio da Perversidade e William Wilson, de Edgar Allan Poe, sob a perspectiva dos conceitos psicanalíticos de Sigmund Freud, principalmente o inquietante (Unheimliche). Ambos os contos exploram aspectos da psique humana os quais seriam posteriormente explicados pelo inovador trabalho de Freud. A primeira parte deste estudo foca no diálogo entre a literatura e o conceito freudiano do inquietante. Em seguida o conceito é aplicado a uma leitura do conto O Demônio da Perversidade, em que Poe apresenta sua própria teoria da natureza fragmentada da mente humana. Na terceira parte deste estudo, os conceitos da perversidade e do inquietante nos auxiliam a analisar o conto William Wilson, uma das mais célebres narrativas sobre o tema do duplo. As leituras interpretativas e os paralelos traçados reforçam os diálogos entre o trabalho ficcional do escritor americano Edgar Allan Poe e as revolucionárias ideias de Freud, as quais sustentam as bases da psicologia moderna.

Palavras-chave: Edgar Allan Poe, Sigmund Freud, Uncanny, Imp of the Perverse, William Wilson. 


\section{THE UNCANNY AND ITS RELATION TO LITERATURE}

The Austrian neurologist Sigmund Freud, the father of psychoanalysis, was an avid reader and relied heavily on his literary repertoire in probing the human mind. Perhaps the most overt manifestation of this literary influence is the so-called "Oedipus complex", a key concept in Freudian theory of psychosexual development, named after Sophocles' protagonist in the tragedy Oedipus Rex. Many other literary texts inspired Freud, since literature has always aimed at representing, one way or another, the central object of psychoanalysis: human nature. Psychoanalysis and literature also share an interest in narratives: the psychoanalytical method uses the telling of narratives to bring to the surface what lies within the unconscious, shedding light on seemingly forgotten experiences, feelings, sensations and impressions which remain deeply embedded in the human psyche, therefore quietly influencing one's behavior. Jerrold Hogle $(2002$, p.3) defines the unconscious as 'a deep repository of very old, infantile, and repressed memories or impulses, the archaic underworld of the self', and accessing this "black box" is central to psychoanalysis, since:

The division of the psychical into what is conscious and what is unconscious is the fundamental premiss of psycho-analysis; the state in which the ideas existed before being made conscious is called by us repression, and we assert that the force which instituted the repression and maintains it is perceived as resistance during the work of analysis. Thus we obtain our concept of the unconscious from the theory of repression. The repressed is the prototype of the unconscious for us. (FREUD, 1957, p.2-3) 
Thus, the repression is central to Freud's revolutionary tripartite definition of the human psyche, yet 'the unconscious does not coincide with the repressed; it is still true that all that is repressed is unconscious, but not all that is unconscious is repressed' (1957, p.6). Part of the ego is actually unconscious, but not repressed; what is repressed lies within the id, as he explains: 'For the ego, perception plays the part which in the id falls to instinct. The ego represents what may be called reason and common sense, in contrast to the id, which contains the passions' (1957, p.10). This tension between conscious and unconscious, acknowledged and repressed, sane and traumatic experiences lies at the center of that what makes us humans consciousness - and it also informs the way we perceive and react to the world around us, a phenomenon Freud discussed in several works, particularly in the seminal essay Das Unheimliche, first published in 1919.

In this essay, Freud proposes a psychoanalytical reading of E. T. A. Hoffmann's short story Sandman in which Nathanael, the protagonist, is shocked and frightened by a number of disturbing circumstances. The first of these events is when Nathanael meets Coppola, a man who looks impressively like a menacing man named Coppelius, whom he had met as a child and whose image bodied forth the mythic figure of the Sandman in his childhood nightmares. The second disturbing situation arises when Nathanael realizes that the woman he is in love with, Olimpia, is in fact a doll, which is revealed in a shocking scene in which the protagonist sees Olimpia without her eyes, for her eyeballs are being replaced. The image of a loved one missing the eyeballs with no sight of blood, 
but simply empty orbits instead, added to Nathanael's childhood fear of the Sandman, a collector of eyes, aptly exemplify Freud's concept of the uncanny.

His contention is that, upon reading Hoffmann's story, the reader, along with the protagonist, experiences something that was hidden from sight, concealed, which is then unexpectedly revealed, thus causing a "shock", precisely one of the definitions for the term Heimliche: 'Concealed, kept from sight, so that others do not get to know of or about it, withheld from others (FREUD, 2003, p.22)'. However, the term also means 'belonging to the house or the family [...], intimate, friendly comfortable; the enjoyment of quiet content, etc.' (2003, p.22). So, being Unheimliche the opposite of Heimliche, it is the opposite of comfortable, thus pointing to that which is disturbing yet somehow familiar, such as a known face or thing out of its usual place.

The feeling that arises from situations that echo one's past, therefore familiar, butin uneasy and disturbing ways, is what Freud means by 'Unheimliche'. The term was translated as "uncanny" in the English Standard Edition of the Complete Psychological Works of Sigmund Freud (1953-1974). However, Freud explores subtleties of meaning which the English term does not encompass:

The German word 'unheimlich' is obviously the opposite of 'heimlich' ['homely'], 'heimisch' ['native'] -the opposite of what is familiar; and we are tempted to conclude that what is 'uncanny' is frightening precisely because it is not known and familiar. Naturally not everything that is new and unfamiliar is frightening, however; the relation is not capable of inversion. (2003, p.124) 
Therefore, we can understand the term Unheimliche as that which is not from home, which causes estrangement and fear of a difficult explanation, for it is, at the same time, strangely homely. Freud states that the uncanny

is undoubtedly related to what is frightening-to what arouses dread and horror; equally certainly, too, the word is not always used in a clearly definable sense, so that it tends to coincide with what excites fear in general. Yet we may expect that a special core of feeling is present which justifies the use of a special conceptual term. One is curious to know what this common core is which allows us to distinguish as 'uncanny' certain things which lie within the field of what is frightening. (2003, p.123)

According to him, the uncanny can take different shapes in real life than it does in literature. In the former, it occurs either 'when infantile complexes which have been repressed are once more revived by some impression, or when primitive beliefs which have been surmounted seem once more to be confirmed' (2003, p.155). In literature, however, there are other ways in which the uncanny may be experienced, since, in fiction, the world may be ruled by distinct aspects. Therefore,

The contrast between what has been repressed and what has been surmounted cannot be transposed on to the uncanny in fiction without profound modification; for the realm of phantasy depends for its effect on the fact that its content is not submitted to reality testing. The somewhat paradoxical result is that in the first place a great deal that is not uncanny in fiction would be so if it happened in real life; and in the second place that there are many more means of creating uncanny effects in fiction 
than there are in real life. The imaginative writer has this licence among many others, that he can select his world of representation so that it either coincides with the realities we are familiar with or departs from them in what particulars he pleases. (2003, p.155-156)

Literary uncanniness, which is our focus here, may also be caused by that which was supposed to stay hidden but has come out into the open, such as repressed feelings. Freud discusses this concept by appropriating Schelling's definition of the term as: "concealed, kept from sight, so that others do not get to know of or about it, withheld from others" (FREUD, 2003, p.22)

These definitions of mental states and feelings associated to the Unheimiliche resonate some of Edgar Allan Poe's principles and motifs, particularly those found in the short stories The Imp of The Perverse and William Wilson. The connection between Poe's works and Freud's psychoanalysis has been pointed out by Hogle in his introduction to the Cambridge Companion to Gothic Fiction:

several features of the Gothic, especially as practiced in the mid-nineteenth century by Edgar Allan Poe in America and the romans frénétiques (or "frenetic novels") in France, eventually became a basis for Sigmund Freud's fin de siècle sense of the unconscious.(HOGLE, 2002, p.3)

Hence, considering how much literature influenced Freud's theories, it is productive to investigate to what extent psychoanalysis may help us interpret literary texts. That is particularly the case of works such as Poe's Gothic stories, which so aptly explore the uncanny as defined by Schelling and Freud. In the following sections, we propose an analysis of Poe's The Imp of The Perverse in the light of 
this Freudian concept, followed by a psychoanalytical reading of the celebrated doppelgänger story William Wilson.

\section{THE UNCANNY IN POE}

American writer Edgar Allan Poe is most widely known for his production of stories which can be considered Gothic due to the presence of haunted places, supernatural themes and other topoi which entertain by means of "curdling the blood", (HAYES, 2004, p.78). Those, however, are only a part of the poet's body of work:

though different groupings have been proposed as a means to organise his texts, even a cursory analysis of his diverse fictional prose indicates three broad categories he explored with different stylistic resources and for different purposes: the tales of ratiocination, founders of detective literature; those of allegory and satire, usually aimed at social and literary criticism; and those generally regarded as the gothic tales. (INDRUSIAK, 2018, p.45-46)

Poe was a very prolific fictional writer and literary critic. He wrote everything from poetry to essays, from literary reviews to short stories and even a novel. Though his short stories vary in tone and theme, going from crime fiction, which he pioneered, to horror stories, through dark comedies, adventures and science fiction, they all share the poet's obsession with the functioning of the human mind.

As Scott Peeples reminds us, Poe was hardly the first writer to explore the inner workings, puzzles and traps of the mind, but 'he dramatized to a startling degree a number of the concepts Freud would name and establish as the fundamentals of modern 
psychoanalysis' (PEEPLES, 2004, p.38). The very narrative structure of many of his tales mirrors the psychoanalytical method; a typical Poe's narrator tells the reader his experiences and impressions not simply in order to account for events as they happened, but to try to make sense of them and to cope with his mental state through the process of narration. In such texts, Poe plunges deep into the narrator's mind, revealing to the reader even more than the narrator is able to reveal to himself. As Gargano concludes, 'Poe understands them [the narrators] far better than they understand themselves. Indeed, he so often designs his tales as to show his narrators' limited comprehension of their own problems and states of mind' (GARGANO Apud ZIMMERMAN, 2005, p.15).

A fitting example of Poe's understanding of human psychology may be found in the short story The Imp of the Perverse, published for the first time in the July edition of Graham's Lady's and Gentleman's Magazine in 1845. In it the narrator details the strange impulse one sometimes has to 'act without comprehensible object; or, if this shall be understood as a contradiction in terms, we may so far modify the proposition as to say, that through its promptings we act, for the reason that we should not' (POE, 2006, p.717). This description summarizes a recurrent theme in Poe's tales: the interference of the protagonist's unconscious leading him towards an unwanted and dreaded path of self-destruction. Tales such as The Tell-tale Heart, The Black Cat, Berenice and William Wilson dramatize as unnatural forces or doppelgängers this same principle which is presented and pondered upon in a philosophical tone in The Imp of the Perverse. Poe's words build the underground of his characters' minds, and that is where many of his stories take place. 'All this 
underground vault business in Poe only symbolizes that which takes place beneath the consciousness - not Poe's consciousness, but the consciousness" (PEEPLES, 2004, p.35). By exploring what lies beneath consciousness, Poe plunges into the unconscious. As noted by G.R. Thompson 'Poe's subject is the precariously logical human mind', he has a 'power to touch the unseen, the unconscious, to suggest the demonic in mankind and its nature' (THOMPSON Apud PEEPLES, 2004, p.82).

Thompson's analysis applies perfectly to The Imp of the Perverse. The story tells us about a man who committed a murder and cannot help giving himself away. However, the reader is only informed about the crime and the confession at the end of the tale; what we find along the first eight paragraphs is the narrator considering reasons for acts he deems perverse, which, according to the character, is 'an innate and primitive principle of human action, a paradoxical something, which we may call perverseness, for want of a more characteristic term' (POE, 2006, p.717).

In his thorough study of Poe's style, Brett Zimmerman calls attention to the level of artistry involved in this seemingly odd definition of perverseness in the opening of a fictional tale. It is an effective rhetorical device called

praeparatio (preparing an audience before telling them about something done): [...] "The Imp of the Perverse" begins with a short dissertation on that destructive and irresistible human impulse before the narrator provides three examples of it and finally his own case. [...] This essay-like introduction is not a failure of craft, as one critic contends, but a measure of Poe's craftiness". (ZIMMERMAN, 2005, p.36-37) 
To exemplify the perverse behavior, Poe refers to fairly harmless everyday practices such as procrastination, but he also associates the principle to more disturbing human traits, such as the tendency one may feel to jump when standing at the edge of an abyss. He opens the discussion by criticizing phrenology for having failed in its search for an answer to man's reasoning. The narrator goes on to question the religious principle according to which man was made by God for a purpose and, accordingly, everything in the human anatomy exists for a reason, every action is taken for a reason that contributes to man's survival, as he details in the following paragraph:

It was the design of the Deity that man should eat. We then assigned to man an organ of alimentiveness, and this organ is the scourge with which the Deity compels man, will-I nill-I, into eating. Secondly, having settled it to be God's will that man should continue his species, we discovered an organ of amativeness, forthwith. And so with combativeness, with ideality, with causality, with constructiveness, -- so, in short, with every organ, whether representing a propensity, a moral sentiment, or a faculty of the pure intellect. (POE, 2006, p.716)

That being so, it seems that everything about humanity would be quite logical and explainable by reason. However, how does one explain when humans perform acts of pure cruelty, or simply acts that are harmful to themselves or to others without taking any sort of advantage in such endeavors? How does reason explain such occurrences? Though seemingly illogical, these paradoxical impulses raised by Poe reinforce the Freudian concept of the uncanny: 'What 
is feared is thus a secret intention of doing harm, and certain signs are taken to mean that that intention has the necessary power at its command' (FREUD, 2003, p.147). That secret intention, in Poe, is, precisely, "the imp of the perverse", a will to do harm for no logical reason, as exposed in the tale:

The one unconquerable force which impels us, and alone impels us to its prosecution. Nor will this overwhelming tendency to do wrong for the wrong's sake, admit of analysis, or resolution into ulterior elements. It is a radical, a primitive impulse-elementary. (POE, 2006, p.717)

Now the origin of this impulse is what puzzles us. If it is not guided by reason, where, then, lies the source of such primitive force? That is where the psychoanalytical concept of the unconscious relates to the imp of the perverse, for the origin of this drive does not lie on the surface of the human psyche, where we can find reasonable explanations. It lies within the hidden part of the mind to which we have no access through reason, and, despite its suppressed nature, it may exert great influence over us.

Thus, we can see how ahead of his time Edgar Allan Poe was, exploring, almost half century before Freud's first publications, how the individual finds an explanation for his/her evil actions in his/her own self, instead of trying to blame them on external sources. It seems fitting to conclude, then, that as with many other psychological concepts, the unconscious was first addressed by literature.

Freud explains the unconscious as that part of the mind which is repressed, therefore separated from the ego, as well as different from what he calls the critical agency: 
I believe that when poets complain that two souls dwell in the human breast, and when popular psychologists talk of the splitting of people's egos, what they are thinking of is this division (in the sphere of ego-psychology) between the critical agency and the rest of the ego, and not the antithesis discovered by psycho-analysis between the ego and what is unconscious and repressed. It is true that the distinction between these two antitheses is to some extent effaced by the circumstance that foremost among the things that are rejected by the criticism of the ego are derivatives of the repressed. (FREUD, 2003, p.161)

Borrowing from the psychoanalytical theory, we can classify the imp of the perverse as an effect of repressed feelings which lie in the unconscious and take shape in actions for which the critical agency, the rational mind, finds no reasonable explanation. Such repressed feelings relate to the uncanny when their echoes trigger memories or thoughts that take unexpected shapes during adulthood and give way to an interesting "perverse" compulsion:

It is possible to recognize the dominance in the unconscious mind of a 'compulsion to repeat' proceeding from the instinctual impulses and probably inherent in the very nature of the instincts-a compulsion powerful enough to overrule the pleasure principle, lending to certain aspects of the mind their daemonic character, and still very clearly expressed in the impulses of small children; a compulsion, too, which is responsible for a part of the course taken by the analyses of neurotic patients. All these considerations prepare us for the discovery that whatever reminds us of this inner 'compulsion to repeat' is perceived as uncanny. (FREUD, 2003, p.145) 
It is quite interesting to note that Poe's understanding of perverseness is so closely tied to Freudian uncanniness that in spite of the differences in style and goals, both authors use similar terminologies. Freud associates to our instinctive compulsion to repeat a daemonic character; Poe, a master of the use of supernatural and eerie images, relates human perverseness to an imp, "a small demon or devil", according to the Collins Dictionary. Certainly, many of Poe's original readers may have read his story as a tale of a man haunted by a little demon in his mind. Contemporary audiences, however, tend to interpret the tale of the selfincriminating narrator from a psychoanalytic stance, demonstrating how Freudian Poe was even before Freud came along, an apparent paradox that corroborates Jorge Luis Borges's contention that great authors create their own precursors (BORGES, 1999).

In addition to demons and imps, Poe's and Freud's works are also related by their references to the human instinctual drives behind pain and pleasure, as explained in Beyond the Pleasure Principle:

Every psycho-physical movement rising above the threshold of consciousness is charged with pleasure in proportion as it approximates-beyond a certain limit-to complete equilibrium, and with "pain" in proportion as it departs from it beyond a certain limit; while between the two limits which may be described as the qualitative thresholds of "pain" or pleasure, there is a certain area of aesthetic indifference. (FREUD, 2010, p.5)

Also according to Freud, the human psyche is guided by opposite drives represented by Eros, the life drive that compels self-preservation, and Thanatos, the death and destruction drive. 
'Eros and Thanatos work together and in the same direction, always seeking the individual's balance'1 ${ }^{\prime 2 A N I N I, ~ 2015, ~ p .100, ~ o u r ~}$ translation). Therefore, the destructive impulses of Poe's narrators - treated in his oeuvre as cases of perverseness - may be read as attempts at establishing some balance within themselves. But the death drive, Thanatos, is often represented by Poe in some characters' need to relive traumatic and uncanny situations, a common human obsession that finds explanation in the Freudian principle of "compulsion to repeat".

Poe's narrator in The Imp of the Perverse is inclined to fall victim of this obsession with deceiving and doing harm to himself. Like this narrator, many other Poean characters fall for their insistence in treading paths which they should have left behind, going from consciousness back to unconsciousness, a movement Daniel Hoffman compares to the symbolic return to the womb:

The womb is the well fount of our unconsciousness before we emerge into the pains of consciousness, and in the womb we are imbued with that instinctual knowledge of our own past, our own beginnings, the state of unity toward we ever after yearn. But to attain that state after being banished from it by out birth - this is to court, to seek, to embrace destruction. (HOFFMAN, 1972, p.146)

In Poe's fiction moving towards one's own past as well as seeking to understand that which must remain concealed within one's mind is a road to destruction, a road one takes when guided by the death drive, Thanatos, which the poet calls perverseness. In Freud, however, this same movement is the key to sanity, provided equilíbrio do indivíduo. 
it be conducted by a skilled psychoanalyst. Unleashing that which has been repressed within the unconscious corners of the mind is disturbing to Poe's narrator: 'We tremble with the violence of the conflict within us, -- of the definite with the indefinite -- of the substance with the shadow. But, if the contest have proceeded thus far, it is the shadow which prevails, -- we struggle in vain' (POE, 2006, p.718). This inner conflict is often triggered by the uncanny, an external manifestation or echo of the shadows hidden within.

Poe's story reaches its climax before the announcement that there has been a crime, while the narrator ponders on the nature and presence of the imp of the perverse and describes the impulse to jump off a cliff and give in to self-destruction:

We stand upon the brink of a precipice. We peer into the abyss -- we grow sick and dizzy. Our first impulse is to shrink from the danger. Unaccountably we remain. By slow degrees our sickness and dizziness and horror become merged in a cloud of unnamable feeling. By gradations, still more imperceptible, this cloud assumes shape, as did the vapor from the bottle out of which arose the genius in the Arabian Nights. But out of this our cloud upon the precipice's edge, there grows into palpability, a shape, far more terrible than any genius or any demon of a tale, and yet it is but a thought, although a fearful one, and one which chills the very marrow of our bones with the fierceness of the delight of its horror. It is merely the idea of what would be our sensations during the sweeping precipitancy of a fall from such a height. And this fall -- this rushing annihilation -for the very reason that it involves that one most ghastly and loathsome of all the most ghastly and loathsome images of death and suffering which 
have ever presented themselves to our imagination -- for this very cause do we now the most vividly desire it. And because our reason violently deters us from the brink, therefore do we the most impetuously approach it. There is no passion in nature so demoniacally impatient, as that of him who, shuddering upon the edge of a precipice, thus meditates a Plunge. To indulge, for a moment, in any attempt at thought, is to be inevitably lost; for reflection but urges us to forbear, and therefore it is, I say, that we cannot. If there be no friendly arm to check us, or if we fail in a sudden effort to prostrate ourselves backward from the abyss, we plunge, and are destroyed. (POE, 2006, p.718)

The passage reveals how far the narrator believes the imp of the perverse is able to take him: to his own annihilation, willingly. Even though his rational mind knows this action to be harmful, an urge drives him along the dark path, for a reason which he cannot explain. As Freud puts it, 'What is feared is thus a secret intention of doing harm, and certain signs are taken to mean that that intention has the necessary power at its command' (FREUD, 2003, p.147). Though the rational mind is able to perceive the self-destructive drive, it cannot make sense of it, for it has no direct access to that which stems from the unconscious. In psychoanalysis, the role of the therapist is to assist and guide the individual in probing his/her unconsciousness for what lies repressed therein, building bridges between the id and the ego. Poe's characters, however, do not have the luxury of such specialized guidance and therefore fall prey to their demons, surrendering to self-destructive impulses, such as in The Imp of the Perverse, or giving in to elaborate disorders of split personalities, such as in the Gothic doppelgänger story William Wilson. 


\section{THE IMP OF THE PERVERSE WILLIAM WILSON}

First published in 1839 in the Burton's Gentleman's Magazine, William Wilson is regarded as one of the best literary works on the theme of the doppelgänger, also known as the double. According to Otto Rank, in William Wilson, 'Edgar Allan Poe used the theme of the double in a way that has become a model for several later treatments' (RANK, 1971,p.25).

According to Ralph Tymms, the ubiquitous theme of the double may be regarded 'as an allegorical representation or as a projection of the second self of the unconscious' (TYMMS, 1949, p.40). However, when it comes to Poe, the term allegory calls for some further explanation, since he dismisses the use of this figure of speech in his critical review of Nathaniel Hawthorne's Twice Told-Tales:

In defence of allegory, (however, or for whatever object, employed,) there is scarcely one respectable word to be said. Its best appeals are made to the fancy--that is to say, to our sense of adaptation, not of matters proper, but of matters improper for the purpose, of the real with the unreal, having never more of intelligible connection than has something with nothing, never half so much of effective affinity as has the substance for the shadow. The deepest emotion aroused within us by the happiest allegory, as allegory, is a very, very imperfectly satisfied sense of the writer's ingenuity in overcoming a difficulty we should have preferred his not having attempted to overcome. The fallacy of the idea that allegory, in any of its moods, can be made to enforce a truth--that metaphor, for example, may illustrate as well as embellish an argument--could be promptly demonstrated: the 
converse of the supposed fact might be shown, indeed, with very little trouble--but these are topics foreign to my present purpose. One thing is clear, that if allegory ever establishes a fact, it is by dint of overturning a fiction. (POE, 1850, p.188)

Yet, Poe is not entirely against allegory; he simply condemns the random and obvious manner in which the literary resource was employed by some of his fellow men of letters. According to Hoffman, Poe's own balanced and proficient use 'restores allegory [...] to its deserving place in our affections' (HOFFMAN, 1972, p.147). Therefore, the piece of criticism above is not at odds with the one below, in which the writer exposes a defense of allegorical writing

Where the suggested meaning runs through the obvious one in a very profound under-current, so as never to interfere with the upper one without our own volition, so as never to show itself unless called to the surface, there only, for the proper uses of fictitious narrative, is it available at all. (POE, 1847, p.252-6, Apud HOFFMAN, 1972, p.147)

In William Wilson, the suggested meaning is the protagonist's unconscious drive to self-destruction, the hidden part of his mind that passes judgement on his own wrongdoings, which is allegorically represented by his double. By calling the allegory to surface and interpreting it, we notice the story's psychoanalytical bent: the seemingly supernatural tale of a doppelgänger reveals a fairly ordinary case of psychological disorder caused by the struggle between the cruel instincts of a man and his guilty conscience. As Hoffman puts it:

Poe's fallen creatures are indeed twice self-doomed, doubly victims of their Imp of the Perverse. First 
their spirit of perversity compels them to commit atrocities and unreasonable crimes - to torture a cat, to murder the wife, to terrify and kill the benevolent old man. The second, equally gratuitous act of perversity is, after having committed the Perfect Crime (all the more perfect for its gratuitousness), inexorably to incriminate oneself by leading the policeman to the exact spot where the victim is entombed. (HOFFMAN, 1972, p.12)

If in The Imp of the Perverse Poe represents the repressed forces of the unconscious through the image of an independent, demonic entity - the imp -, in William Wilson the poet takes one further step in the characterization of such forces as intrinsic to the individual's mind, personified in the exact mirrored image of the protagonist. The protagonist and his double share their name, date of birth, and physical traits; only one thing seems to differentiate them: the voice. As the narrator tells us: 'even my voice did not escape him. My louder tones were, of course, unattempted, but then the key, it was identical; 'and his singular whisper, it grew the very echo of my own' (POE, 2006, p.320). Hence, even when something is there to tell them apart, such as a whispering voice, it actually becomes one more factor that unites them, since one's voice is the echo of the other's, which indicates that the whole existence of the double is also an echo of that of the narrator's. Despite its eerie nature, though, the double is not responsible for evil acts or cruel inclinations. On the contrary, the struggle between Wilson and his double is caused by the latter's attempts to denounce and stop Wilson's dissolute life.

Since the result of this life-long struggle is self-destruction, the double in William Wilson may be interpreted as an allegory 
that stands for the same impulses represented by the imp of the perverse. However, as Wilson's double is willing to do right and expose the protagonist's dark secrets, he may also be regarded as a representation of the life drive, Eros, while the protagonist himself is guided by Thanatos, the death drive. The tale, then, reads as a metaphor for an individual's struggle to reach a steady balance between these unconscious and interdependent forces, so that one's attempt to subdue the other results is their mutual destruction in the final scene of the short story:

I was frantic with every species of wild excitement, and felt within my single arm the energy and the power of a multitude. In a few seconds I forced him by sheer strength against the wainscoting, and thus, getting him at mercy, plunged my sword, with brute ferocity, repeatedly through and through his bosom. (POE, 2006, p.328)

Being Poe an advocate of the painstaking choice of precise words, no term or phrase should ever be neglected in interpretive readings of his work. In that sense, two words from the quote above deserve special attention: "wild" and "multitude". While the former points to the nature of human instincts, the latter reinforces Poe's avant la lettre psychoanalytical bent, stressing the plurality of voices and forces within an individual's mind.

Graphic as it may be, this final scene in which Wilson kills his rival and then realizes that this violent act entails his own destruction lends itself to more than one interpretation. Certainly, the allegory does not point to a simple suicide; since the double represents a projection of Wilson's unconscious, his killing is symbolic. What is murdered along with his double may not be 
Wilson himself, but his reason, his mind, irrevocably damaged once the balance between Eros and Thanatos is permanently lost. But this death may also be interpreted as the liberating and healing experience of coming to terms with one's unconscious, the necessary - yet sometimes painful - process of shedding light on and acknowledging repressed feelings and memories that feed neurosis, thus paving the way for a new, healthier psyche. Since the story of William Wilson is rationally told in homodiegetic analepsis (i.e. first-person flashback), it would not be too far-fetched to contend that the narrating Wilson is this new, more balanced man, who buried his wicked former self, the experiencing Wilson, by embracing his dual nature. Conversely, we could also argue that the narrative voice is that of a deeply disturbed man who can hardly recall the events that led to his losing his mind.

At any rate, it seems clear that psychoanalytical readings of Poe's tales such as William Wilson and The Imp of the Perverse reveal complexity and sophistication that tend to go unnoticed in the superficial analyses often reserved to stories of gruesome and supernatural undertones. More importantly, however, such readings reinforce the dialogue between psychology and literary studies, a dialogue greatly intensified by Poe and Freud in their explorations of the human mind.

\section{REFERENCES}

BORGES, Jorge Luis (1999). "Kafka e seus precursores". In: Obras Completas. Vol. II. São Paulo: Globo, p.96-98.

hOFFMAN, Daniel (1972). Poe, Poe, Poe, Poe, Poe, Poe, Poe. Paragon House (Eds.) Reprint. Originally published: Garden City, New York: Doubleday. 
FREUD, Sigmund (2010). Beyond the Pleasure Principle. London; Vienna: The International Psycho-Analytical Library Press, Rosings Digital Publications. Inhttps:// www.librarything.com/publisherseries/The+International+Psycho-Analytical+Library Accessed on 3.Mar.2019.

(2003). The Uncanny. David McLintock (Trans. and Eds). London, England: Penguin Classics.

(1957) The Ego and the Id. Joan Riviere (Trans.). London, England:Hogarth Press.

HAYES, Kevin, J (2004). The Cambridge Companion to Edgar Allan Poe. Cambridge, United Kingdom: Cambridge University Press.

HOGLE, Jerrold E. (2002). The Cambridge Companion to Gothic Fiction. United States of America by Cambridge University Press, New York: Cambridge University Press.

IMP. In Collins Dictionary. Retrived In https://www.collinsdictionary.com/ dictionary/english/impon Accessed on 3.Mar.2019.

INDRUSIAK, Elaine B. (2018) "Narrative Suspense in Edgar Allan Poe and Alfred Hitchcock". English Literature Theories, Interpretations, Contexts, 5. Flavio Gregori (Eds.), 39-58. In https://edizionicafoscari.unive.it/media/pdf/journals/englishliterature/2018/5/iss-5-2018_qyIW25\%20Accessed\%20Q.pdf Accessed on 3.Mar.2019. POE, Edgar Allan (1847). Godey's Lady's Book. November, (35), p.252-6 In https:// www.ibiblio.org/eldritch/nh/nhpoe2.html Accessed on 28.Nov.2018.

(1850). "Nathaniel Hawthorne" (Text-B), In: The Works of the Late Edgar Allan Poe 3:188-202. https://www.eapoe.org/works/criticsm/hawthgr. htm Accessed on 8.Jan.2019.

(2006). "The Imp of the Perverse" In: The Complete Tales and Poems of Edgar Allan Poe. New York: Barnes\&Noble, p.716-720.

(2006). "William Wilson" In: The Complete Tales and Poems of Edgar Allan Poe. New York: Barnes\&Noble, p.314-329.

PEEPLES, Scott. (2004) The Afterlife of Edgar Allan Poe. Rochester, NY: Camdem House.

RANK, Otto. (1971) Double: A Psychoanalytic Study. Harry Tucker Jr. Charlotte (Trans. and Eds.). North Carolina: The University of North Carolina Press. 
TYMMS, Ralph (1949). Doubles in Literary Psychology. Cambridge: Cambridge University Press.

ZANINI, Claudio (2015). "O Perverso e o Gótico em Jogos Mortais". Revista Abusões 1(1), Rio de Janeiro, RJ, UERJ.

ZIMMERMAN, Brett (2005). Edgar Allan Poe: Rhetoric and Style. Canada, Quebec: McGill-Queen's University Press. 